\title{
The MinK Potassium Channel Exists in Functional and Nonfunctional Forms When Expressed in the Plasma Membrane of Xenopus Oocytes
}

\author{
Edward M. Blumenthal ${ }^{1, a}$ and Leonard K. Kaczmarek ${ }^{1,2,3}$ \\ 1'Interdepartmental Neuroscience Program, 2Department of Pharmacology, and ${ }^{3}$ Department of Cellular and Molecular \\ Physiology, Yale University School of Medicine, New Haven, Connecticut 06510
}

\begin{abstract}
The minK protein induces a slowly activating voltage-dependent potassium current when expressed in Xenopus oocytes. In order to measure the levels of minK protein in the plasma membrane, we have modified the mink gene by inserting a 9 amino acid epitope into the $\mathrm{N}$-terminal domain of the protein sequence. When intact live oocytes are injected with the modified minK RNA and subsequently incubated with an antibody to this epitope, specific binding is detected, indicating that the $\mathrm{N}$-terminal domain is extracellular. We found that when oocytes are injected with amounts of minK mRNA up to $50 \mathrm{ng}$, the levels of protein at the surface are proportional to the amount of injected mRNA. In contrast, the amplitude of the minK current recorded in the oocytes saturates at $1 \mathrm{ng}$ of injected mRNA. Although the amplitude of the currents is not altered by increasing mRNA levels above $1 \mathrm{ng}$, the kinetics of activation of the current differ in oocytes with high or low levels of minK RNA. In particular, activation is slower with higher levels of minK protein in the plasma membrane. Finally, we find that increasing intracellular cAMP levels, which increases the amplitude of minK currents, does not alter surface expression of the minK protein but produces a small increase in the rate of activation of the current. Our results support a model in which mink protein forms functional potassium channels by association with a factor endogenous to the oocyte.
\end{abstract}

[Key words: potassium channel, oocyte, epitope tag, minK, modulation, cAMP-dependent protein kinase]

The minK potassium channel (also called $I_{\mathrm{sk}}$ ) has several unusual features. Expressed in heart (Folander et al., 1990), secretory epithelia (Pragnell et al., 1990; Sugimoto et al., 1990), and lymphocytes (Attali et al., 1992), the minK protein contains only 129-130 amino acids and one proposed transmembrane helix, and has no sequence homology to other known proteins (Takumi et al., 1988; Murai et al., 1989). This is in contrast to all other ion channel proteins cloned thus far, which are far larger and have multiple transmembrane domains (Kaczmarek, 1991; Ho et al., 1993; Kubo et al., 1993). When expressed in

\footnotetext{
Received July 2, 1993; revised Oct. 21, 1993; accepted Nov. 1, 1993.

We thank Drs. Chris Miller and Steve Goldstein for the artificial minK gene. This work was supported by NIH Grant GM-48851 to L.K.K.

Correspondence should be addressed to Dr. Leonard Kaczmarek, Department of Pharmacology, Yale Medical School, 333 Cedar Street, New Haven, CT 06510.

aPresent address: Department of Biology, 0357, University of California-San Diego, La Jolla, CA 92093.

Copyright (C) 1994 Society for Neuroscience $0270-6474 / 94 / 143097-09 \$ 05.00 / 0$
}

oocytes of the frog Xenopus laevis, $\operatorname{minK}$ induces a voltageactivated potassium current with extremely slow activation kinetics. Upon membrane depolarization, the minK current increases over tens of seconds, at least 2 orders of magnitude more slowly than any other ion channel.

The unusual nature of the minK protcin initially caused many researchers to doubt that it directly forms ion channels and to suggest that it induces the expression of endogenous oocyte channels. It has been shown, however, that mutagenesis of specific residues in the transmembrane domain alters the ionic selectivity of the resulting channels, indicating that the $\operatorname{minK}$. protein is very likely to be a structural component of the channel pore (Goldstein and Miller, 1991). These experiments do not resolve, however, whether the minK channel is a homomultimer or is formed by $\operatorname{minK}$ in association with one or more endogenous proteins.

Much of the work on minK has examined the modulation of the potassium current. Despite the small size of the minK protein, its current is modulated by a variety of second messenger systems. Protein kinase $C$ phosphorylates the $\operatorname{minK}$ protein and shifts its voltage dependence of activation (Busch et al., 1992a). Raising intracellular calcium increases the current amplitude, possibly through the activation of a calcium-activated protein kinase (Honore et al., 1991; Busch et al., 1992b). Finally, activation of the cAMP-dependent protein kinase (PKA) increases the amplitude of the current (Blumenthal and Kaczmarek, 1992). Mutations of the only putative phosphorylation site for PKA in minK do not alter its ability to be modulated by this enzyme, suggesting that PKA acts by phosphorylating some other protein that controls the amplitude of minK current. Because PKA activation causes an increase in the membrane surface area of the oocyte, it has also been proposed that the increase in minK current results from the insertion of vesicles enriched in the minK protein into the plasma membrane (Blumenthal and Kaczmarek, 1992).

We have now examined the relationship between the level of expression of the minK protein and the characteristics of the resulting potassium current. Using the methods of epitope tagging and surface labeling, we find that the amount of $\operatorname{minK}$ protein on the oocyte surface is not correlated with the amplitude of the current, indicating that some factor other than the amount of minK protein determines the number of functional minK channels. In addition, we find that increases in cAMP levels increase the amplitude of $\operatorname{minK}$ currents with no detectable increase in plasma membrane $\operatorname{minK}$ protein. Finally, we find that the activation kinetics of the current are dependent on 


\section{$\mathbf{A}$}

Bluescript KS- $\quad$ Artificial MinK Gene

3' Untranslated Region from Kv1.5 Potassium Channel
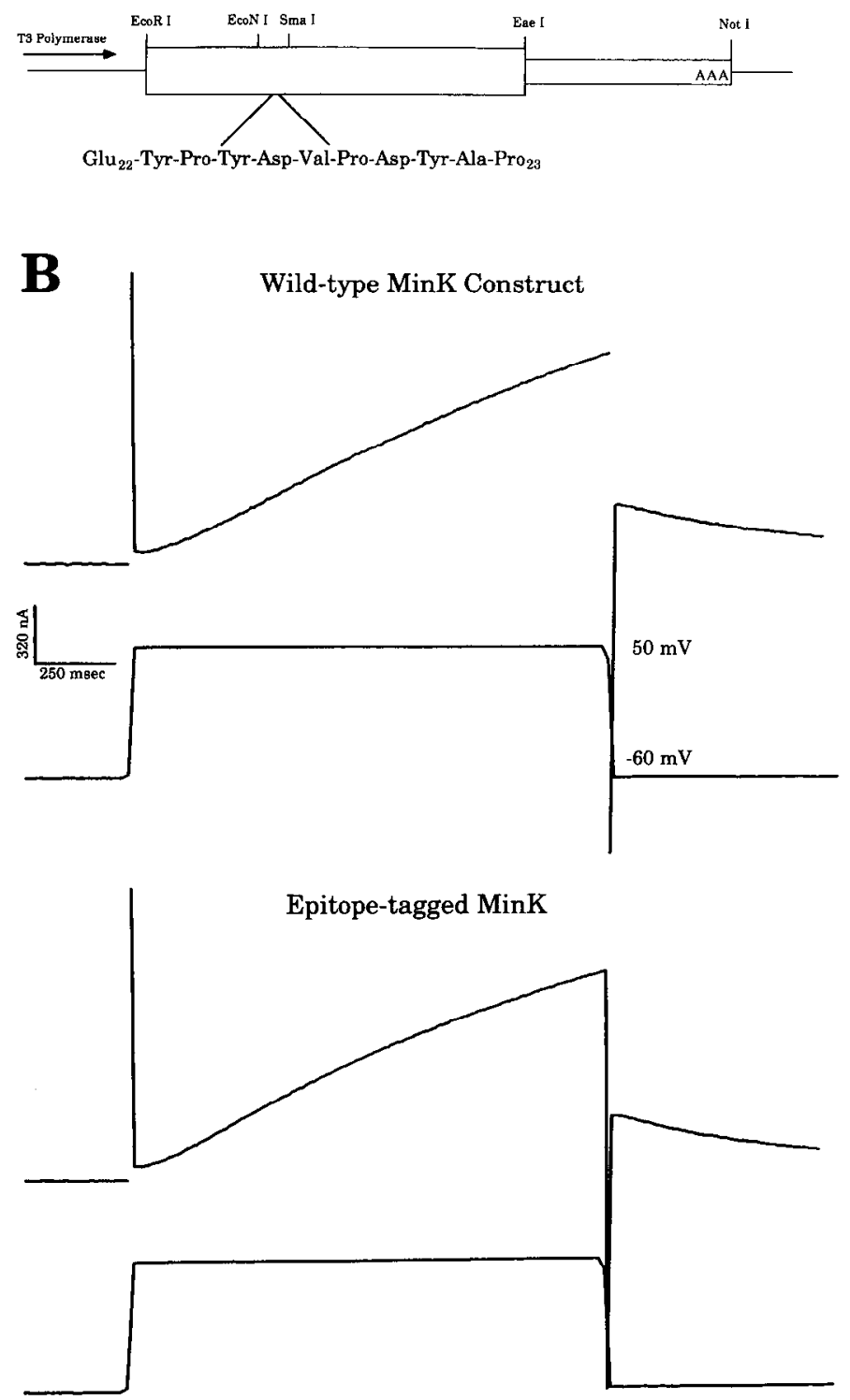

Figure 1. Construction and expression of epitope-tagged and wild-type rat minK genes. $A$, Schematic diagram of the minK constructs used in these studies. The 9 amino acid hemagglutinin epitope is shown, inserted after glutamate-22. See Materials and Methods for details. $B$, Currents recorded from oocytes injected with $10 \mathrm{ng}$ of wild-type (upper panel) or epitope-tagged (lower panel) $\operatorname{minK}$ transcript. The oocytes were held at $-60 \mathrm{mV}$ and depolarized to $50 \mathrm{mV}$ for $1.5 \mathrm{sec}$.

the level of surface expression, and on cAMP levels. We present a model of $\operatorname{minK}$ function incorporating these results.

\section{Materials and Methods}

General molecular biology methods. Digestions and ligations were performed by standard methods (Sambrook et al., 1989). Gel purification was performed either with the Geneclean system (Bio 101, La Jolla, CA) or with DEAE cellulose (Schleicher and Schuell, Keene, NH) (Sambrook et al., 1989). Enzymes were purchased from Boehringer Mannheim (Indianapolis, IN), Promega (Madison, WI), and New England Biolabs (Beverly, MA).

MinK expression constructs. The artificial minK gene (Hausdorff et al., 1991; gift of Dr. S. Goldstein, Brandeis University) was digested with EcoRI and NotI. The 420 base pair (bp) fragment containing the coding region was gel purified and ligated into EcoRI/NotI cut Bluescript $\mathrm{KS}^{-}$(Stratagene, La Iolla, CA); this construct was called minK-2. Two oligonucleotides were prepared (GGCAGGAAACAGATGAGTACCCATATGATGTTCCAGATTACGCTCCC and GGGAGCGTAATCTGGAACATCATATGGGTACTCATCTGTTTCCTGC, prepared by the Yale University Pathology Dept. DNA Synthesizing Service). These oligonucleotides span the region of $\operatorname{minK}$ between the EcoNI and SmaI sites, code for a 9 amino acid epitope from influenza virus hemagglutinin [amino acid sequence YPYDVPDYA (Field et al., 1988), inserted after residue $\mathrm{E} 22$ of $\mathrm{minK}$ ], and contain a unique NdeI site. The oligonucleotides were annealed by heating and cooling in $20 \mathrm{~mm}$ Tris, pH 8.0, $10 \mathrm{mM} \mathrm{MgCl}_{2}, 50 \mathrm{~mm} \mathrm{NaCl}$, and then ligated into min K-2 which had been cut with EcoNI and SmaI. The insertion was confirmed by DNA sequence analysis using the Sequenase system (U.S. Biochemical Corp., Cleveland, $\mathrm{OH}$ ); this construct was called epi-1. To boost expression of the RNA, a $3^{\prime}$ untranslated region and polyA tail were ligated into the construct as follows. The $\mathrm{K}_{v} 1.5$ expression construct (Swanson et al., 1990) was digested with EcoRI and NotI and the 1188 bp fragment was purified. A 373 bp fragment containing most of the $3^{\prime}$ untranslated region and a 40 base polyA tail was isolated following a partial EaeI digest of the $1188 \mathrm{bp}$ fragment. This was ligated into both the $\operatorname{minK}-2$ and epi-1 constructs, both of which had been linearized with NotI, gel purified, and treated with calf intestinal phosphatase (Boehringer Mannheim). The orientation of the insert was confirmed by restriction digests. The epitope-tagged and nonepitope-tagged constructs were named epi-2 and minK-3, respectively (see Fig. $1 A$ ).

Oocyte expression. Epi-2 and minK-3 were linearized with NotI and RNA was transcribed in vitro with T3 polymerase (Boehringer Mannheim or Promega) and purified as described (Blumenthal and Kaczmarek, 1992). The RNA was dissolved in sterile water at either $0.2 \mathrm{mg} /$ $\mathrm{ml}$ or $1 \mathrm{mg} / \mathrm{ml}$. Oocytes from female Xenopus laevis (Nasco, Ft. Atkinson, WI) were isolated as described (Blumenthal and Kaczmarek, 1992) and injected with $50 \mathrm{nl}$ of RNA 2-18 hr later. For injections of less than $10 \mathrm{ng}$ of RNA, the $1 \mathrm{mg} / \mathrm{ml}$ RNA solutions were serially diluted in sterile water immediately before injection. Oocytes were incubated in $\mathrm{OR}_{3}$ medium [ $50 \% \mathrm{~L}-15$ (GIBCO, Grand Island, NY) (without phenol red), $15 \mathrm{~mm}$ HEPES, pH 7.6, $50 \mu \mathrm{g} / \mathrm{ml}$ gentamicin (Sigma, St. Louis, $\mathrm{MO})]$ for $2-5 \mathrm{~d}$ at $19^{\circ} \mathrm{C}$ before use.

Electrophysiology. Oocyte membrane currents were recorded as described previously (Blumenthal and Kaczmarek, 1992). The recording solution contained (in $\mathrm{mm}$ ) $96 \mathrm{Na}$-aspartate, $2 \mathrm{~K}$-aspartate, $0.5 \mathrm{CaCl}_{2}$, $5 \mathrm{MgCl}_{2}, 5$ HEPES, pH 7.6 (NaOH). Oocytes were briefly perfused with recording solution before each voltage pulse, as this appeared to result in more consistent current amplitudes. For $\operatorname{minK}$ amplitude and activation kinetics, a series of four or five $1.5 \mathrm{sec}$ pulses from $-60 \mathrm{mV}$ to $50 \mathrm{mV}$ spaced $15 \mathrm{sec}$ apart were used. The currents were filtered at 1000 $\mathrm{Hz}$, digitized at $100 \mathrm{~Hz}$, and averaged. The amplitude of the minK current was measured as the difference between the current at the end of the pulse and the current immediately after depolarization. For tail current kinetics, the oocytes were held at $-60 \mathrm{mV}$, depolarized once to $50 \mathrm{mV}$ for $2240 \mathrm{msec}$, and returned to $-60 \mathrm{mV} ; 10.5 \mathrm{sec}$ of tail current was recorded. These records were filtered at $20 \mathrm{~Hz}$, and digitized at 14.3 $\mathrm{Hz}$.

The effect of CAMP was measured by injecting groups of oocytes with

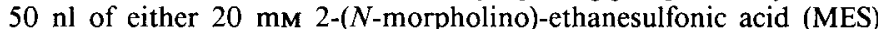
(Calbiochem, La Jolla, CA), pH 7.0, or $500 \mu \mathrm{M}$ cAMP (Sigma) and 500 $\mu_{\mathbf{M}}$ theophylline (Sigma) in $20 \mathrm{~mm}$ MES. Currents were recorded 23$50 \mathrm{~min}$ after injections. Alternatively, oocytes were incubated at room temperature in $\mathrm{OR}_{3}$ containing $1 \mathrm{~mm} 8-\mathrm{Br}-\mathrm{cAMP}$ (Sigma) for $1 \mathrm{hr}$ before recording.

Surface labeling. All procedures were carried out at $4^{\circ} \mathrm{C}$. Groups of eight oocytes were rinsed briefly in assay buffer $[88 \mathrm{~mm} \mathrm{NaCl}, 1 \mathrm{~mm}$ $\mathrm{KCl}, 2.4 \mathrm{~mm} \mathrm{NaHCO}, 1 \mathrm{~mm} \mathrm{MgCl} 2,15 \mathrm{~mm}$ HEPES, pH $7.6(\mathrm{NaOH})]$ containing $4 \%$ bovine serum albumin (BSA; Sigma). The oocytes were incubated with 12CA5 ascites fluid (BAbCo, Richmond, $\mathrm{CA}$ ) diluted 1:100 in assay buffer with BSA for $20 \mathrm{~min}$. The unbound antibody was removed by two washes in assay buffer, and the oocytes were incubated for $45 \mathrm{~min}$ in ${ }^{125}$ I-labeled protein A (ICN, Costa Mesa, CA) $(0.1 \mu \mathrm{g} / \mathrm{ml}$, $85-100 \mathrm{mCi} / \mathrm{mmol}$ ) in assay buffer with BSA. The oocytes were washed four times in assay buffer, placed on filters, and counted in a gamma counter. In experiments with 8-Br-cAMP-treated oocytes, $1 \mathrm{~mm} \mathrm{8-Br-}$ cAMP was included in all steps except the final four washes. For binding in depolarizing conditions, all of the sodium in the assay buffer was replaced by potassium. 


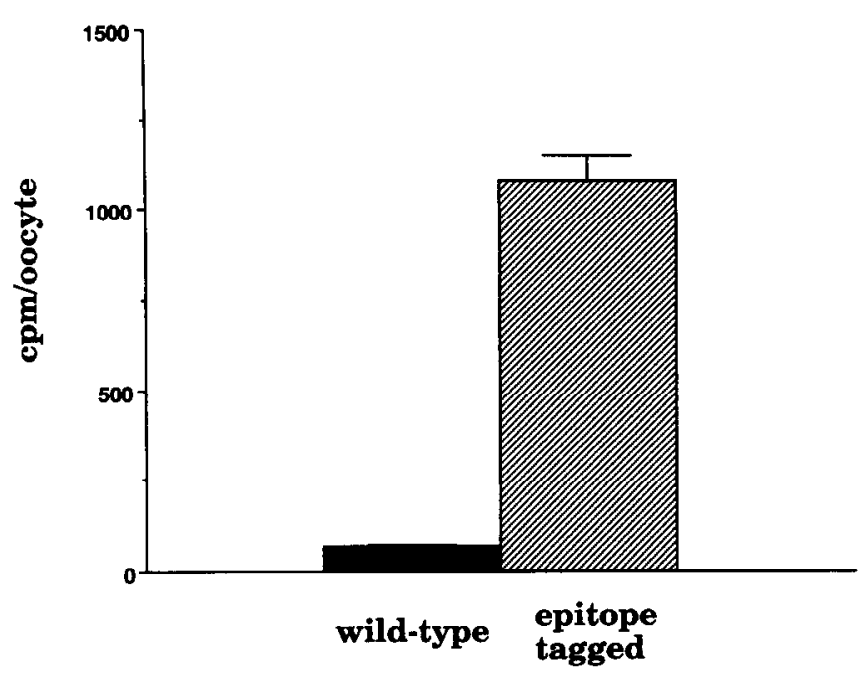

Figure 2. Surface labeling of oocytes expressing epitope-tagged $\operatorname{minK}$. Each value represents the average of eight groups of oocytes, with each group containing eight oocytes. Error bars represent standard errors.

Curve fiting. The digitized data was transferred from the PDP 11 to a Macintosh computer and imported into DELTAGRAPH (Deltapoint, Inc., Monterey, CA). Tail currents were fit by the equation $I(t)=A_{0}+A_{1} \exp (t /$ $\left.\tau_{1}\right)+A_{2} \exp \left(t / \tau_{2}\right)$. Activation was fit by a single exponential and a delay as follows: the initial $150 \mathrm{msec}$ of the trace was deleted and the remaining trace was fit by the equation $I(t)=A_{0}+A_{1}\left[1-\exp \left(t / \tau_{1}\right)\right]$. The delay was defined as the time at which $I(t)$ computed by this equation was equal to the initial amplitude of the measured current trace.

\section{Results}

In order to examine the relationship between mink current and protein expression, we developed an assay to measure the amount of minK protein expressed on the surface of an oocyte. To accomplish this, we constructed a minK gene with a 9 amino acid epitope from influenza virus hemagglutinin (Field et al.,
1988 ) inserted between residues 22 and 23 , a region we assumed was extracellular. The gene we used for this work was an artificial rat minK construct (Hausdorff et al., 1991). In order to boost expression levels, we also added the $3^{\prime}$ untranslated region and polyA tail of the $K_{v} 1.5$ gene (Swanson et al., 1990), which expresses well in oocytes (Fig. 1 $A$ ). The "wild-type" and epitopetagged constructs used in these experiments differed only in the presence of the hemagglutinin epitopc. Injection of the cpitopctagged RNA into Xenopus oocytes resulted in the expression of a slowly activating voltage-dependent potassium current (Fig. $1 B$ ). The currents from the wild-type and epitope-tagged genes appeared identical in amplitude, kinetics, voltage dependence, and in their ability to be modulated by 8 -Br-cAMP (Fig. $1 B$ and data not shown).

We measured the amount of mink protein on the oocyte surface by incubating live oocytes with the monoclonal antibody 12CA5, which recognizes the hemagglutinin epitope. To measure the binding of this antibody, the oocytes were then incubated with ${ }^{125} \mathrm{I}$-labeled protein $\mathrm{A}$. The binding studies were carried out with live oocytes, at $4^{\circ} \mathrm{C}$ and in the absence of detergents. Under these conditions only minK protein expressed on the cell surface should be labeled. We observed a high level of binding to oocytes injected with the epitope-tagged RNA (10 ng), and very low nonspecific binding to oocytes injected with $10 \mathrm{ng}$ of wild-type RNA (Fig. 2). Because these two groups of oocytes differ only in the presence of the epitope, this surface labeling represents binding of the antibody to the minK protein.

Binding of the 12CA5 antibody to the epitope tag was unaffected by activation of the minK channels. We conducted binding assays in media containing high $(100 \mathrm{~mm})$ potassium to depolarize the oocytes and activate the minK current. Under these conditions, specific binding was identical to that seen in normal media (data not shown).

To determine the relation between the amount of RNA injected and the amount of minK protein at the plasma mem-

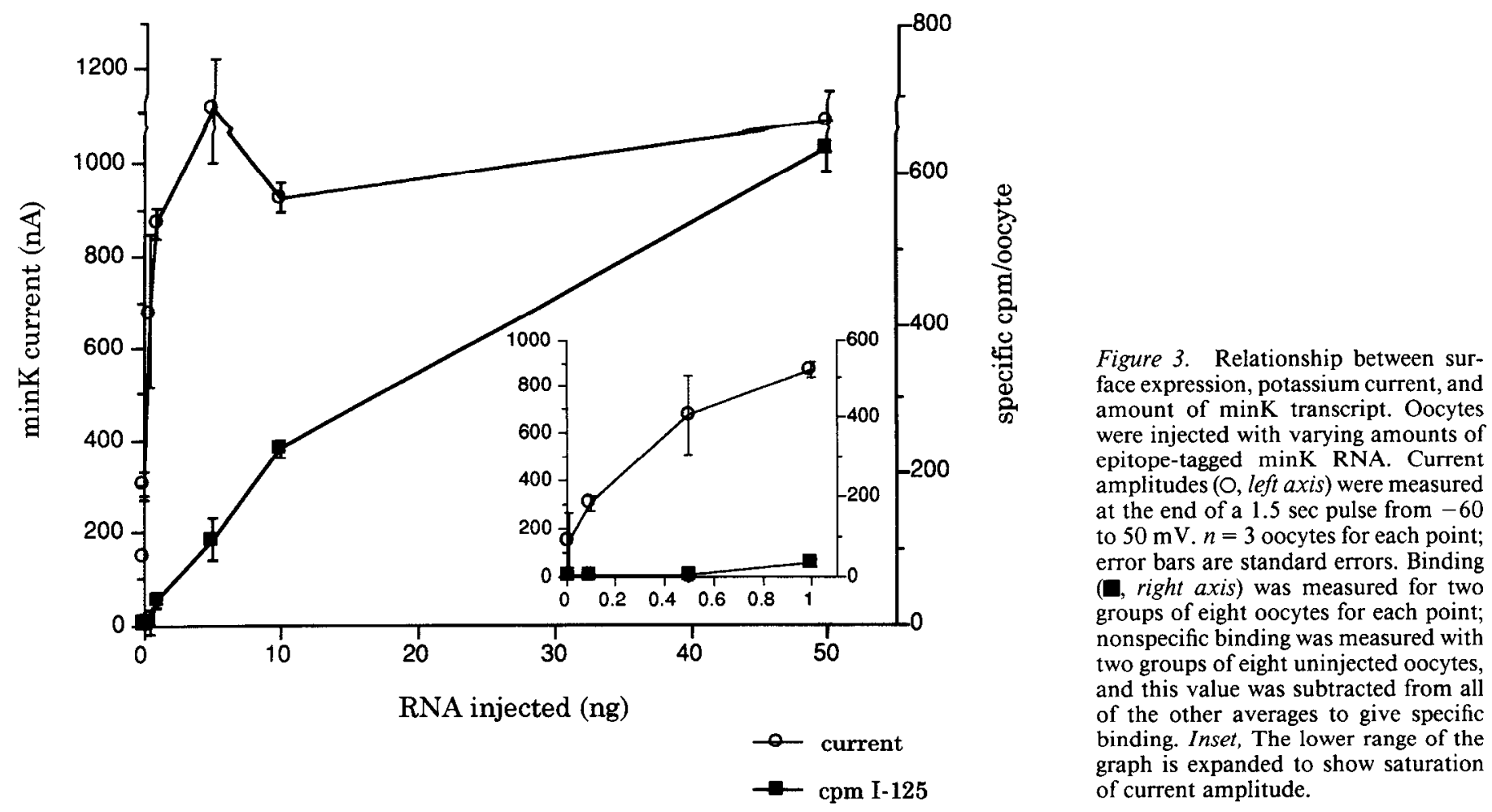


$\mathbf{A}$

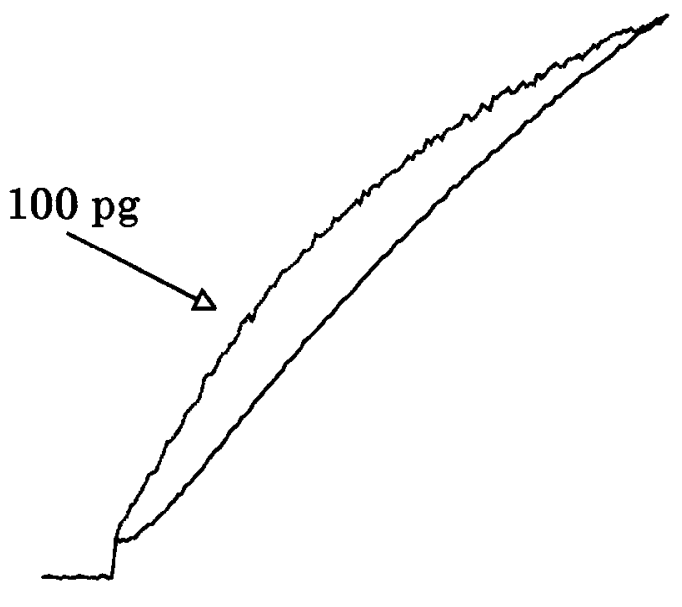

$300 \mathrm{msec}$
B

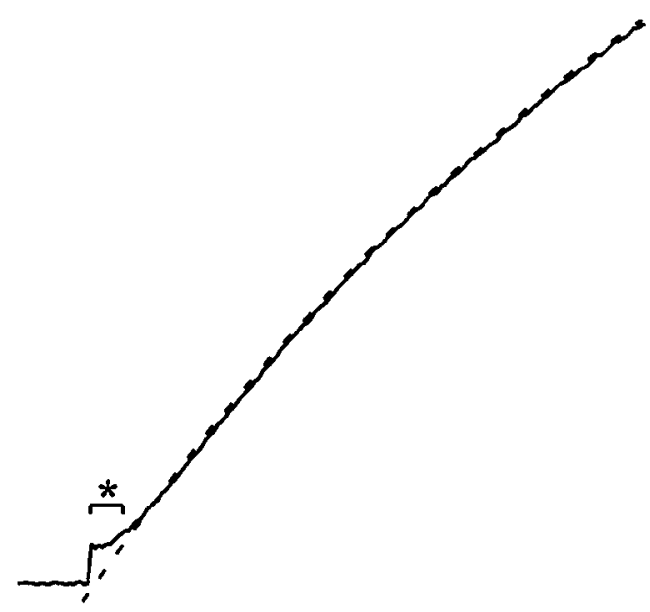

\section{$50 \mathrm{mV}$ \\ $.60 \mathrm{mV}$}

C

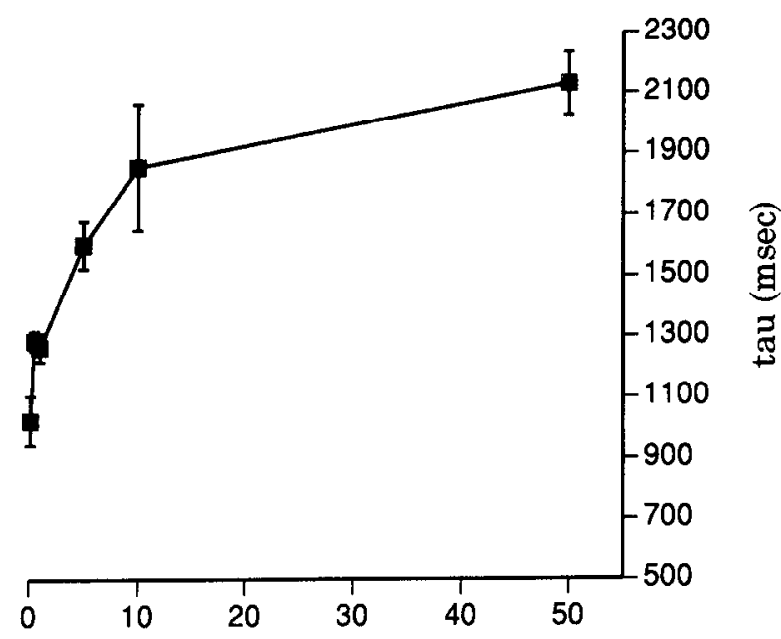

RNA injected (ng)

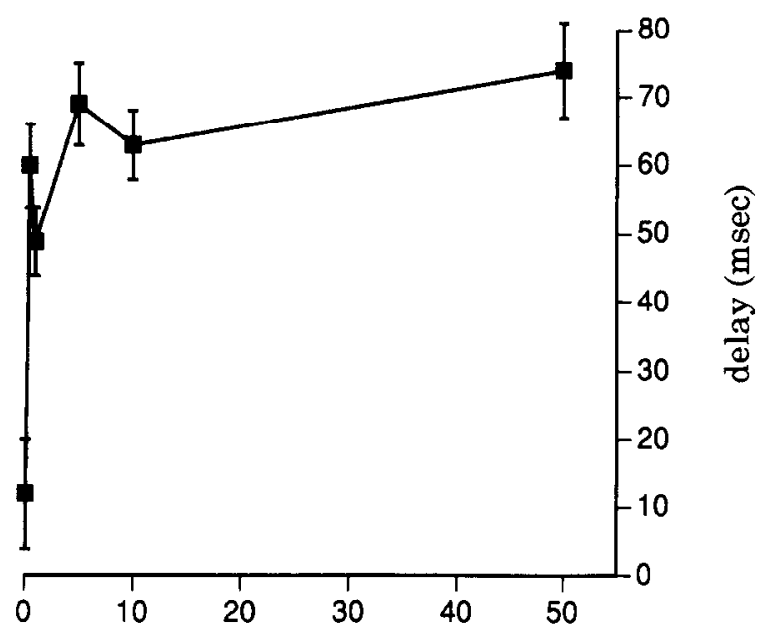

RNA injected (ng)

Figure 4. Relationship between activation kinetics and amount of injected RNA. $A$, Currents from oocytes injected with 100 pg and 50 ng of minK RNA, scaled to emphasize the difference in kinetics. The currents are averages of four pulses from $-60 \mathrm{mV}$ to $50 \mathrm{mV}$ lasting 1.5 sec each. Calibration: $200 \mathrm{nA}(50 \mathrm{ng})$ and $72.5 \mathrm{nA}(100 \mathrm{pg}) . B$, Fifty nanogram current from $A$. The dashed line represents a fit to the equation $I(t)=A_{0}+$ 


\begin{tabular}{rclll}
\hline Table 1. & \multicolumn{5}{c}{ Dependence of tail current kinetics on expression level } \\
$\begin{array}{rllll}\text { RNA } \\
\text { injected }\end{array}$ & \multicolumn{1}{c}{$n$} & $\begin{array}{l}\tau_{1} \\
(\mathrm{msec})\end{array}$ & $\begin{array}{l}\boldsymbol{r}_{2} \\
(\mathrm{msec})\end{array}$ & $A_{2} / A_{1}$ \\
\hline $100 \mathrm{pg}$ & 10 & $686 \pm 44$ & $3040 \pm 200$ & $1.22 \pm 0.10$ \\
$500 \mathrm{pg}$ & 10 & $759 \pm 49$ & $3687 \pm 272$ & $1.45 \pm 0.10$ \\
$1 \mathrm{ng}$ & 10 & $751 \pm 62$ & $3390 \pm 95$ & $1.50 \pm 0.10$ \\
$5 \mathrm{ng}$ & 9 & $697 \pm 33$ & $3358 \pm 403$ & $1.76 \pm 0.08$ \\
$10 \mathrm{ng}$ & 9 & $803 \pm 61$ & $4160 \pm 173$ & $1.78 \pm 0.10$ \\
$50 \mathrm{ng}$ & 11 & $831 \pm 56$ & $4166+339$ & $1.68 \pm 0.16$
\end{tabular}

Data are from fits of tail currents as shown in Figure 5. Oocytes in each group were obtained from two different donor frogs. Values are averages \pm SEM. There is no significant dependence of either time constant on RNA level (weighted linear regressions, $p>0.05$ ). The ratio of amplitudes is also not correlated with RNA level $(p>0.25)$; however, the value at $100 \mathrm{pg}$ is significantly different from those at 5,10 , and $50 \mathrm{ng}(t$ tests, $p<0.05)$.

brane, groups of oocytes were injected with varying amounts of epitope-tagged minK RNA and labeled with antibody and protein $\mathrm{A}$. The relationship between surface expression and message level is shown in Figure 3. Binding was first detectable in oocytes injected with $1 \mathrm{ng}$ of RNA, increased lincarly with incrcasing amounts of transcript up to $10 \mathrm{ng}$, and continued to increase up to $50 \mathrm{ng}$ of RNA, the maximum amount injected in these experiments.

In parallel to the binding experiments described above, the amplitude of minK current was measured following a $1.5 \mathrm{sec}$ depolarization to $50 \mathrm{mV}$. The oocytes used in the current and binding experiments were isolated from the same donor frog and treated identically, and both experiments were performed on the same day. As shown in Figure 3, the relationship between current amplitude and surface protein levels is far from linear. Current can first be detected in oocytes injected with $10 \mathrm{pg}$ of RNA and reaches a maximum level at $1 \mathrm{ng}$. Oocytes injected with $50 \mathrm{ng}$ of RNA did not express any more current than oocytes injected with $1 \mathrm{ng}$. Figure 3 shows results from oocytes from one donor frog; oocytes from a second donor gave identical results.

Although the amplitude of currents is not affected by increasing the amount of RNA injected above $1 \mathrm{ng}$, the increase in surface expression of $\operatorname{minK}$ with larger injections is correlated with a progressive change in the kinetics of activation. Figure $4 A$ shows superimposed traces of currents at the onset of a pulse to $50 \mathrm{mV}$ for oocytes injected with $100 \mathrm{pg}$ and $50 \mathrm{ng}$ of minK RNA. Activation in the oocyte injected with the larger amount of RNA is both slower and delayed when compared to that of the oocyte injected with the lower amount. Because of the very complex time course of minK activation, we adopted an empirical measure to quantitate these changes in kinetics. Although the initial phase of $\operatorname{minK}$ activation upon depolarization to 50 $\mathrm{mV}$ generally follows a sigmoidal time course, we were unable to fit the first $1.5 \mathrm{sec}$ of activation reliably with a sigmoidal function. As shown in Figure $4 B$, however, the currents were wcll fit by a single exponential following a delay, and we used this method to quantitate the activation kinetics (see Materials
A
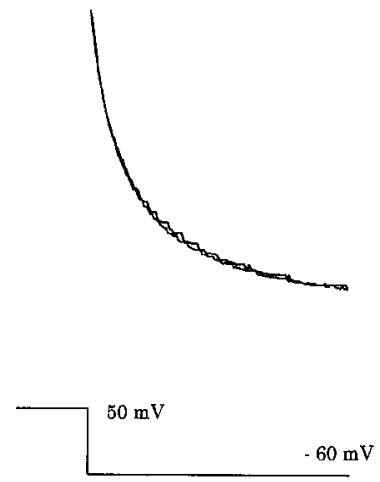

B

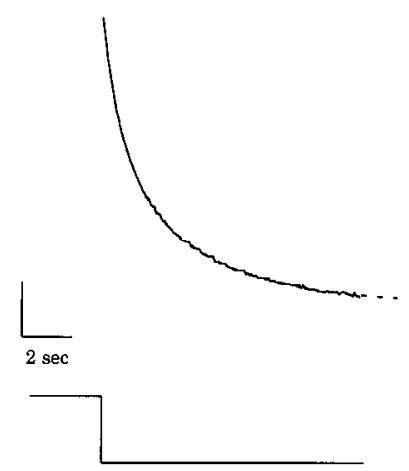

Figure 5. MinK tail currents. $A$, Tail currents from oocytes injected with $500 \mathrm{pg}$ and $50 \mathrm{ng}$ of RNA at $-60 \mathrm{mV}$ following a $2.25 \mathrm{sec}$ pulse to $50 \mathrm{mV}$. The currents have been scaled to emphasize the similar kinetics. Calibration: $20.6 \mathrm{nA}(500 \mathrm{pg})$ and $30 \mathrm{nA}(50 \mathrm{ng}) . B$, Fifty nanogram current from $A$. The dashed line represents a fit to the equation $I(t)=A_{0}+A_{1} \exp \left(t / \tau_{1}\right)+A_{2} \exp \left(t / \tau_{2}\right)$.

and Methods). The amplitude of the activation time constant varied with increasing amounts of RNA, increasing from 1022 msec in $100 \mathrm{pg}$-injected oocytes to $2129 \mathrm{msec}$ in $50 \mathrm{ng}$-injected oocytes (Fig. $4 C$ ). The length of the delay, which reflects the sigmoidal nature of the activation, was independent of RNA level between $500 \mathrm{pg}$ and $50 \mathrm{ng}$ of RNA, but was significantly smaller in oocytes injected with only $100 \mathrm{pg}$ (Fig. 4D). In fact, in this latter group of oocytes, the length of the delay was not significantly different from 0 (one sample $t$ test, $p>0.1, n=$ 19).

Experiments with more prolonged depolarizations showed that the dependence of activation kinetics on RNA level continues beyond the first $1.5 \mathrm{sec}$. Using $10.5 \mathrm{sec}$ pulses to $50 \mathrm{mV}$, a clear difference was observed between oocytes injected with $500 \mathrm{pg}$ and $50 \mathrm{ng}$ of RNA, with the latter currents activating more slowly ( $n=8$ oocytes for each level of RNA, data not shown). As we were unable to fit these currents reliably with a sum of exponentials, we did not quantitate this difference.

To determine whether the kinetics of deactivation, like those of activation, are affected by expression level, we examined minK tail currents at $-60 \mathrm{mV}$ following a $2.25 \mathrm{sec}$ pulse to 50 $\mathrm{mV}$. The first $10.5 \mathrm{sec}$ of the tail current was well fit by a sum of two exponentials (Fig. 5). In contrast to activation, deactivation of minK did not exhibit the same dependence upon the amount of RNA injected. Neither time constant varied significantly with increasing levels of expression (Table 1). As was the case with the delay in activation, however, tail currents in oocytes injected with $100 \mathrm{pg}$ of RNA were different, having a greater proportion of the fast component (Table 1).

\section{Modulation of $\min K$ by $c A M P$}

We have previously shown that activation of PKA by the membrane-permeant cAMP analog 8-Br-cAMP causes an increase in the amplitude of the $\operatorname{minK}$ current (Blumenthal and $\mathrm{Ka}$ -

$A_{1}\left[1-\exp \left(t / \tau_{1}\right)\right]$. Note the sigmoidal nature of the current, as shown by the deviation from the fit curve at the beginning of the pulse. The delay is marked with an asterisk. $C$. Plot of activation time constant versus RNA. Error bars represent standard errors. The values represent averages from $24(500 \mathrm{pg}), 19(100 \mathrm{pg}, 50 \mathrm{ng}), 15(10 \mathrm{ng})$, or $11(1 \mathrm{ng}, 5 \mathrm{ng})$ oocytes from six different donor frogs. The time constant exhibits a significant dependence on RNA level (weighted linear regression, $p<0.05$ ). $D$, Plot of the activation delay versus RNA. Error bars represent standard errors. The delay at $100 \mathrm{pg}$ is less than all other values ( $t$ tests, $p<0.005$ ). There are no differences among the other values (one-way ANOVA, $p>0.05$ ). 


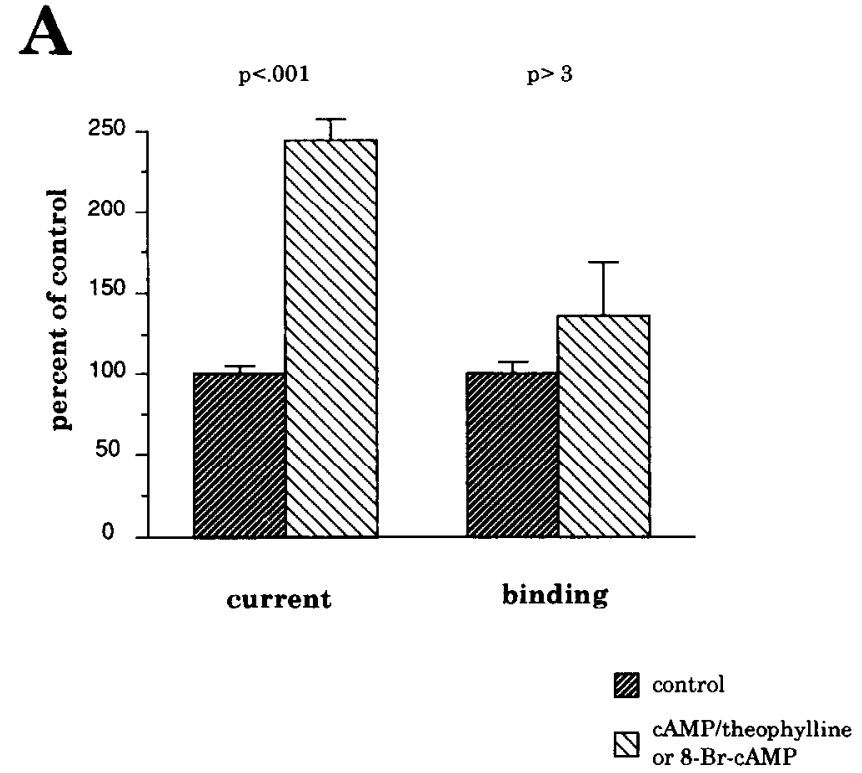

B

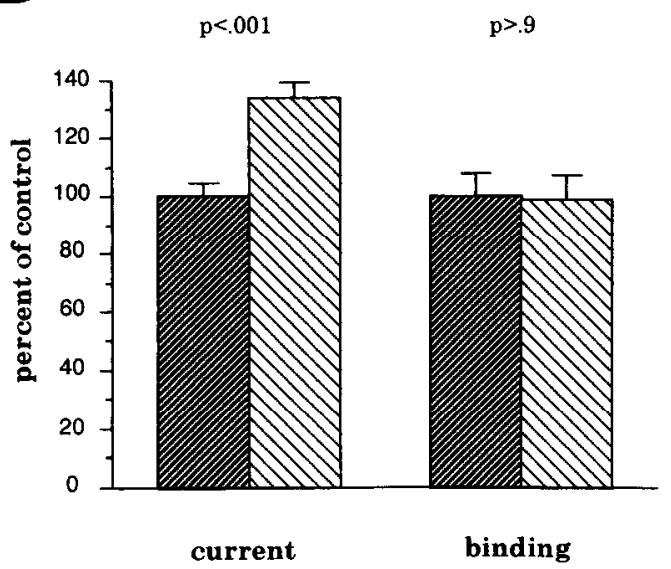

Figure 6. Effect of PKA activation on surface labeling of minK. $A$ Oocytes (which had been injected with 500 pg of RNA) were injected with cAMP/theophylline in MES or with MES. The current values are each averages of four oocytes and have been normalized to the control average. Error bars represent standard errors. The binding study consisted of 16 groups of eight oocytes: four expressing wild-type minK injected with buffer, four epitope-tagged minK injected with buffer, four wild-type $\operatorname{minK}$ injected with $\mathrm{cAMP} /$ theophylline, and four epitopetagged minK injected with cAMP/theophylline. The average $\mathrm{cpm} / \mathrm{oo}-$ cyte was calculated for each group, and then for each treatment the four wild-type values (arranged randomly) were subtracted from the four epitope-tagged values and the differences were normalized to the control average. These normalized differences were then used in the $t$ test to show no significant increase in binding. Error bars represent standard errors. $B$, Similar to $A$, with the following differences: the oocytes were injected with $10 \mathrm{ng}$ of RNA and were incubated for $1 \mathrm{hr}$ in $\mathrm{OR}_{3} \pm 1$ mM 8-Br-cAMP. The average of two experiments from different donors is shown. $n=9$ oocytes total for each current value; $n=8$ groups of eight oocytes for each of the four binding groups described in $A$.

czmarek, 1992). PKA activation also leads to an increase in the surface area of the oocyte membrane. To test the hypothesis that the increase in current amplitude is due to the addition of new minK channels to the oocyte surface, we measured surface expression of minK protein in oocytes injected with either 500 pg or $10 \mathrm{ng}$ of RNA following either injection of cAMP and theophylline or incubation with 8 -Br-cAMP. We found that the injections resulted in a larger, more rapid, and more consistent increase in current amplitude than incubation with 8-Br-cAMP (compare Fig. 6 $A, B$ ). The relative increase in current amplitude was independent of the amount of RNA injected. Regardless of the treatment used or the amount of RNA injected, we observed no significant increase in surface binding (Fig. 6 and data not shown).

We also measured the effect of elevations of intracellular cAMP on the kinetics of activation of minK. By fitting the activation of the current with an exponential function and a delay, we found that the injection of CAMP/theophylline into oocytes expressing minK currents produces a small but statistically significant change in the activation kinetics. The increase in current amplitude is accompanied by a decrease in the time constant of activation and an increase in the delay (Table 2 ). We observed this effect in oocytes injected with either $500 \mathrm{pg}$ or $10 \mathrm{ng}$ of minK RNA.

\section{Discussion}

By constructing an epitope-tagged $\operatorname{minK}$ gene we were able to use antibodies to the epitope to measure surface expression of the minK protein. The insertion of 9 amino acids into the amino-terminal domain of minK does not appear to affect the protein's ability to form functional channels, suggesting that the amino-terminal domain is not essential for ion channel formation. In addition, channel activation does not appear to involve large changes in the conformation of the epitope, as antibody binding was normal under depolarizing conditions. These findings are consistent with the results of Takumi ct al. (1991), who expressed functional minK deletion mutants lacking much of the amino-terminal domain. Our finding that the antibody binds to the surface of live, intact oocytes demonstrates for the first time that the amino-terminal domain of $\operatorname{minK}$ is extracellular. It had been suggested that a site within this domain may be phosphorylated by a calcium/calmodulin-dependent protein kinase (Honore et al., 1991), but our results would argue against this hypothesis. Taken together with the finding that a threonine residue near the carboxyl terminus is the probable substrate of protein kinase $C$ (Busch et al., 1992a), our result supports the current model for the transmembrane topology of $\operatorname{minK}$ : one transmembrane domain with the amino terminus on the extracellular side.

One advantage of the Xenopus oocyte over most other expression systems is the ability to inject defined amounts of RNA and thereby vary the level of expression of exogenous proteins. We have used this technique to examine the relationships among the amount of minK RNA injected into the oocyte, the amount of minK protein expressed on the oocyte surface, and the amplitude and kinetics of the minK current. The amount of $\operatorname{minK}$ protein on the surface of the oocyte varies with the amount of RNA injected, indicating that injections of up to $50 \mathrm{ng}$ of $\mathrm{minK}$ RNA do not saturate the translational machinery of the oocyte. If the minK protein alone were capable of forming potassium channels, one would expect from this result that the current amplitude would also vary linearly with RNA, and that the kinetics of the current would be independent of RNA level. The actual behavior of $\operatorname{minK}$, however, is quite different.

Our most striking result is that the amplitude of the $\min K$ current, measured after a $1.5 \mathrm{sec}$ activation, saturates with $1 \mathrm{ng}$ of injected RNA. Oocytes injected with $50 \mathrm{ng}$, which contain at least 20 -fold more minK protein at the plasma membrane, do not express any additional current. This result can be ex- 
Table 2. Effect of cAMP/theophylline injection on minK kinetics

\begin{tabular}{llllll}
$\begin{array}{l}\text { RNA } \\
\text { injected }\end{array}$ & Treatment & $n$ & $\begin{array}{c}\text { Amplitude } \\
\text { (nA) }\end{array}$ & $\tau(\mathrm{msec})$ & Delay (msec) \\
\hline $500 \mathrm{pg}$ & MES & 8 & $735 \pm 67$ & $1646 \pm 138$ & $68 \pm 2$ \\
& cAMP/theo & 8 & $1573 \pm 113^{* *}$ & $1307 \pm 74^{*}$ & $79 \pm 2^{* *}$ \\
$10 \mathrm{ng}$ & MES & 4 & $1174 \pm 94$ & $3275 \pm 475$ & $38 \pm 13$ \\
& cAMP/theo & 5 & $1961 \pm 39^{* *}$ & $1812 \pm 144^{*}$ & $78 \pm 4^{*}$
\end{tabular}

Data are from fits of $1.5 \mathrm{sec}$ activations as in Figure 4. Currents were recorded 23-50 min after injections of either cAMP/theophylline in MES or MES. Values are averages \pm SEM.

* Significantly different from controls, $t$ test, $p<0.05$.

** $p<0.005$.

plained if minK exists in two forms in the oocyte membrane: a functional form and a nonfunctional form. This hypothesis assumes that there is an absolute limit to the size of the functional pool of protein, and that limit is reached in oocytes injected with $1 \mathrm{ng}$ of RNA. Any additional protein that reaches the membrane would be nonfunctional and would not contribute to the current amplitude.

There are two possible mechanisms for generating functional and nonfunctional minK protein in the plasma membrane. First, minK might become functional by interacting with an endogenous oocyte factor. Such a factor could be a site on the cytoskeleton, a protein subunit, or a rare lipid. After this factor is exhausted, additional minK protein would be recruited to the nonfunctional pool. The other explanation is that the two pools arise from different biosynthetic pathways. If the oocytes were only capable of synthesizing and correctly processing a certain amount of minK to produce functional protein, any additional protein might be processed incorrectly and not be able to form functional channels. Although our results do not distinguish between these two mechanisms, the first mechanism could explain why it has been difficult to express $\operatorname{minK}$ in cells other than Xenopus oocytes. Oocytes may possess a necessary factor that other cell types lack. Such a factor could be expressed in the oocyte because it performs some other function, or it may be present because oocytes normally express $\operatorname{minK}$ channels at some point during their development. Evidence in favor of this latter explanation is that oocytes of the frog Rana pipiens do express a slowly activating voltage-dependent potassium current during one stage of their development (Schlichter, 1989). Recently, functional expression of $\operatorname{minK}$ has been reported in HEK293 cells, which are derived from kidney (Frceman and Kass, 1993). Since minK is normally expressed in the kidney, HEK293 cells may also express the required factor.

If minK channels are indeed composed of more than one type of functionally distinct subunit, they would not be unique among potassium channels. Isolation of Shaker-like potassium channel complexes from native tissue using toxin or antibodies reveals an associated protein of approximately $38 \mathrm{kDa}$ molecular mass (Rehm and Lazdunski, 1988; Trimmer, 1991; Parcej et al., 1992). In addition, the properties of potassium channels expressed in Xenopus oocytes can be modified by coinjection of a low-molecular-weight RNA fraction from rat brain (Rudy et al., 1988). Nevertheless, the additional subunits that these studies suggest may exist for Shaker-like channels differ from the putative minK factor in that they are probably not required for channel expression.

Any explanation of the function of $\operatorname{minK}$ must also take into account our observations of the kinetics of the current. Increas- ing the amount of minK protein causes the current to activate more slowly. In addition, oocytes injected with $100 \mathrm{pg}$ of RNA, which presumably express only functional protein, display currents whose initial phase of activation can be approximated well by an exponential function. In contrast, oocytes injected with $500 \mathrm{pg}$ or more RNA express sigmoidally activating currents. The change in activation kinetics indicates that the $\operatorname{minK}$ channels do not function independently of each other. Somehow, an excess of minK protein on the oocyte surface interferes with the ability of the channel to respond to depolarization. Thus the "nonfunctional" pool of minK protein discussed above is not truly nonfunctional, but rather inhibits activation by interacting with the "functional" protein (Fig. 7). The activation kinetics therefore reflect the ratio of functional to nonfunctional protein, while a sigmoidal time course reflects the presence of nonfunctional protein. The kinetics of minK deactivation (tail currents) are not as dependent upon the amount of nonfunctional protein on the oocyte surface. The simplest explanation of this is that once the minK channels are activated, they are no longer affected by the nonfunctional min K protein (Fig. 7), although other models with more complex interactions among the proteins could also be consistent with our data.

Our finding that minK channels may interact is in contrast to the traditional theory that ion channels function independently. Other recent findings challenge this theory for more "well-behaved" potassium channels. It has been reported that the kinetic and pharmacological properties of Shaker-like potassium channels are altered in oocytes injected with very high levels of channel RNA (Guillemare et al., 1992; Honore et al., 1992; Moran et al., 1992). However, because protein levels were not measured in these latter studies, it is unclcar whether the results parallel those we have described for $\operatorname{minK}$ channels.

Finally, we have used the surface labeling technique to examine the mechanism of cAMP-dependent modulation of the minK current. Previous work has shown that activation of PKA by cAMP analogs increases the amplitude of the minK current without affecting its voltage dependence (Blumenthal and $\mathrm{Ka}$ czmarek, 1992). This increase in current is accompanied by an increase in the capacitance of the oocyte membrane, providing the hypothesis that PKA activation leads to the insertion of minK protein into the plasma membrane. We have now found that the amount of minK protein on the surface of the oocytes does not change following activation of PKA. Nevertheless, as pointed out above, not all of the minK protein in these oocytes (which had been injected with either 500 pg or $10 \mathrm{ng}$ of RNA) is functional. We cannot therefore eliminate the possibility that an elevation of $\mathrm{c} \Lambda \mathrm{MP}$ levels produces a selective insertion of the activating factor or subunit, or of functional minK channels, 
A Low minK concentration

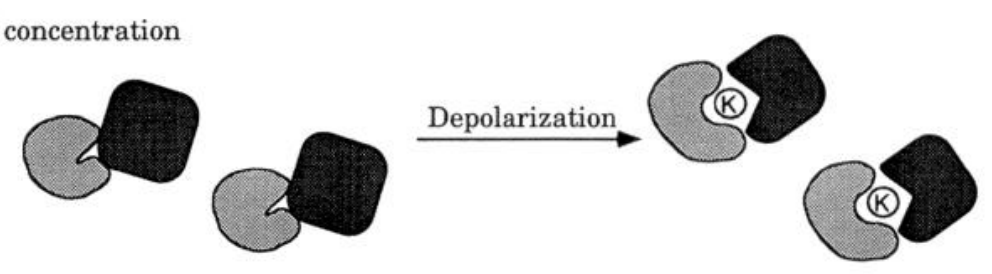

Figure 7. Model of minK function. A, In oocytes injected with low amounts of minK transcript, all of the minK protein (light shading) associates with an endogenous factor (dark shading). Upon depolarization, these complexes form active potassium channels. $B$, At higher concentrations of $\operatorname{minK}$ protein, much of the $\operatorname{minK}$ protein is not associated with the endogenous factor and is nonfunctional (hatched). This additional protein interferes with the activation of the minK potassium channels. See Dis-

B High $\operatorname{minK}$ concentration cussion for details.

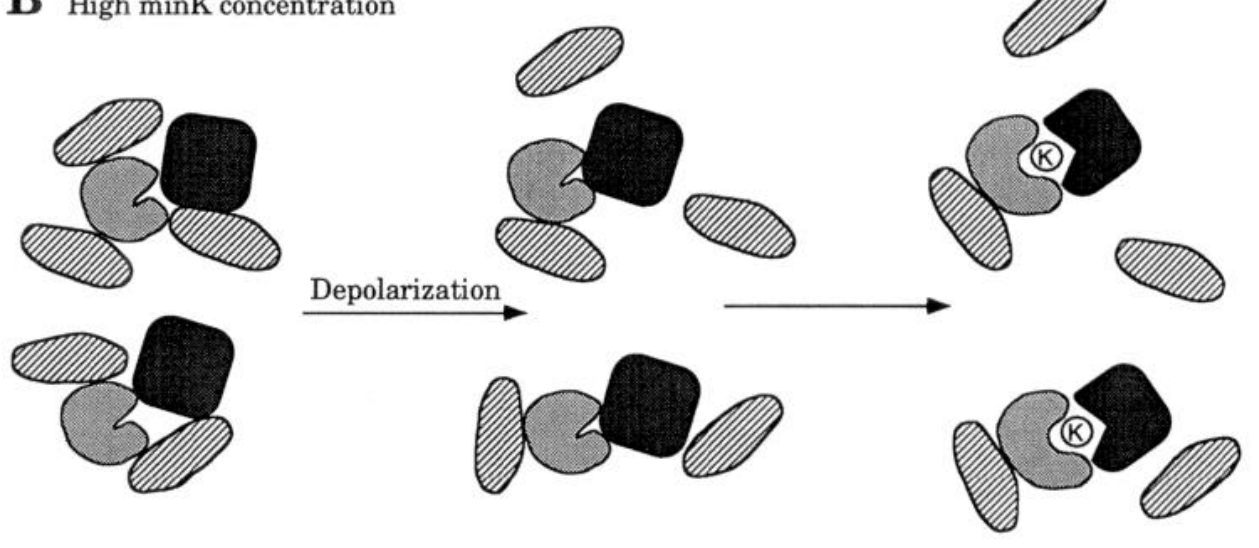

from subplasmalemmal vesicles into the plasma membrane. Our result is reminiscent of another example of cAMP-dependent modulation, that of nicotinic ACh receptors in chick ciliary ganglion neurons. In those cells, a small fraction of the surface nicotinic ACh receptors are active, and cAMP increases the nicotinic response without detectable addition of receptors (Margiotta et al., 1987). The mechanism of this modulation remains unknown.

Previous work on the action of cAMP analogs on minK currents in oocytes had suggested that the increase in current was not accompanied by any marked changes in its kinetics of activation (Blumenthal and Kaczmarek, 1992). By carrying out a more quantitative analysis of the effects of injecting cAMP and theophylline into oocytes, we have now found that the increase in current is associated with a significant decrease in the time constant of activation (Table 2). This finding is consistent with the notion that cAMP increases the amount of activating factor for the current. Because our model suggests that the time constant is governed by the ratio of functional to nonfunctional minK protein, a selective increase in the amount of activating subunit or factor in the plasma membrane would be expected to increase that ratio and decrease the time constant of activation. According to the data presented in Figure $4 D$, however, such an increase should be accompanied by no change in the activation delay, rather than the increase that we observed (Table 2). Clearly, further investigations into both the effects of cAMP and the identity and mechanism of action of the activating factor are necessary before these effects are fully understood.

\section{References}

Attali B, Romey G, Honore E, Schmid-Alliana A, Mattei M-G, Lesage F, Ricard P, Barhanin J, Lazdunski M (1992) Cloning, functional expression, and regulation of two $\mathrm{K}^{+}$channels in human T-lymphocytes. J Biol Chem 267:8650-8657.

Blumenthal EM, Kaczmarek LK (1992) Modulation by cAMP of a slowly activating potassium channel expressed in Xenopus oocytes. J Neurosci 12:290-296.
Busch AE, Varnum MD, North RA, Adelman JP (1992a) An amino acid mutation in a potassium channel that prevents inhibition by protein kinase C. Science 255:1705-1707.

Busch AE, Kavanaugh MP, Varnum MD, Adelman JP, North RA (1992b) Regulation by second messengers of the slowly activating, voltage-dependent potassium current expressed in Xenopus oocytes. J Physiol (Lond) 450:491-502.

Field J, Nikawa J-I, Broek D, MacDonald B, Rodgers L, Wilson IA, Lerner RA, Wigler M (1988) Purification of a RAS-responsive adenylyl cyclase complex from Saccharomyces cerevisiae by use of an epitope addition method. Mol Cell Biol 8:2159-2165.

Folander K, Smith JS, Antanavage J, Bennett C, Stein RB, Swanson R (1990) Cloning and expression of the delayed-rectifier $I_{\mathrm{sk}}$ channel from neonatal rat heart and diethylstilbestrol-primed rat uterus. Proc Natl Acad Sci USA 87:2975-2979.

Freeman LC, Kass RS (1993) minK: expression in mammalian (HEK293 ) cells and immunolocalization in guinea pig heart. Biophys J 64 : A341.

Goldstein SAN, Miller C (1991) Site-specific mutations in a minimal voltage-dependent $\mathrm{K}^{+}$channel alter ion selectivity and open-channel block. Neuron 7:403-408.

Guillemare E, Honore E, Pradier L, Lesage F, Schweitz H, Attali B, Barhanin J, Lazdunski M (1992) Effects of the level of mRNA expression on biophysical properties, sensitivity to neurotoxins, and regulation of the brain delayed-rectifier $\mathrm{K}^{+}$channel $\mathrm{K}_{\mathrm{v}} 1.2$. Biochemistry $31: 12463-12468$.

Hausdorff SF, Goldstein SAN, Rushin EE, Miller C (1991) Functional characterization of a minimal $\mathrm{K}^{+}$channel expressed from a synthetic gene. Biochemistry 30:3341-3346.

Ho K, Nichols CG, Lederer WJ, Lytton J, Vassilev PM, Kanazirska MV, Hebert SC (1993) Cloning and expression of an inwardly rectifying ATP-regulated potassium channel. Nature 362:31-38.

Honore E, Attali B, Romey G, Heurteaux C, Ricard P, Lesage F, Lazdunski M, Barhanin J (1991) Cloning, expression, pharmacology and regulation of a delayed rectifier $\mathrm{K}^{+}$channel in mouse heart. EMBO J 10:2805-2811.

Honore E, Attali B, Romey G, Lesage F, Barhanin J, Lazdunski M (1992) Different types of $\mathrm{K}^{+}$channel current are generated by different levels of a single mRNA. EMBO J 11:2465-2471.

Kaczmarek LK (1991) Voltage-dependent potassium channels: $\operatorname{minK}$ and Shaker families. New Biol 3:315-323.

Kubo Y, Baldwin TJ, Jan YN, Jan LY (1993) Primary structure and functional expression of a mouse inward rectifier potassium channel. Nature 362:127-133.

Margiotta JF, Berg DK, Dionne VE (1987) Cyclic AMP regulates the 
proportion of functional acetylcholine receptors on chicken ciliary ganglion neurons. Proc Natl Acad Sci USA 84:8155-8159.

Moran O, Schreibmayer W, Weigl L, Dascal N, Lotan I (1992) Level of expression controls modes of gating of a $\mathrm{K}^{+}$channel. FEBS Lett 302:21-25.

Murai T, Kakizuka A, Takumi T, Ohkubo H, Nakanishi S (1989) Molecular cloning and sequence analysis of human genomic DNA encoding a novel membrane protein which exhibits a slowly activating potassium channel activity. Biochem Biophys Res Commun 161:176181.

Parcej DN, Scott VES, Dolly JO (1992) Oligomeric properties of $\alpha$-dendrotoxin-sensitive potassium ion channels purified from bovine brain. Biochemistry 31:11084-11088.

Pragnell M, Snay KJ, Trimmer JS, MacLusky NJ, Naftolin F, Kaczmarek LK, Boyle MB (1990) Estrogen induction of a small, putative $K^{+}$channel mRNA in rat uterus. Neuron 4:807-812.

Rehm H, Lazdunski M (1988) Purification and subunit structure of a putative $\mathrm{K}^{+}$-channel protein identified by its binding properties for dendrotoxin I. Proc Natl Acad Sci USA 85:4919-4923.

Rudy B, Hoger JH, Lester HA, Davidson N (1988) At least two mRNA species contribute to the properties of rat brain A-type potassium channels expressed in Xenopus oocytes. Neuron 1:649-658.

Sambrook J, Fritsch EF, Maniatis T (1989) Molecular cloning: a laboratory manual, 2d ed. Cold Spring Harbor, NY: Cold Spring Harbor Laboratory.
Schlichter LC (1989) Ionic currents underlying the action potential of Rana pipiens oocytes. Dev Biol 134:59-71.

Sugimoto T, Tanabe Y, Shigemoto R, Iwai M, Takumi T, Ohkubo H, Nakanishi S (1990) Immunohistochemical study of a rat membrane protein which induces a selective potassium permeation: its localization in the apical membrane portion of epithelial cells. J Membr Biol $113: 39-47$

Swanson R, Marshall J, Smith JS, Williams JB, Boyle MB, Folander $\mathrm{K}$, Luneau CJ, Antanavage J, Oliva C, Buhrow SA, Bennett C, Stein RB, Kaczmarek LK (1990) Cloning and expression of cDNA and genomic clones encoding three delayed rectifier potassium channels in rat brain: Neuron 4:929-939.

Takumi T, Ohkubo H, Nakanishi S (1988) Cloning of a membrane protein that induces a slow voltage-gated potassium current. Science 242:1042-1045.

Takumi T, Moriyoshi K, Aramori I, Ishii T, Oiki S, Okada Y, Ohkubo $H$, Nakanishi $S$ (1991) Alteration of channel activities and gating by mutations of slow $I_{4 k}$ potassium channel. J Biol Chem 266:2219222198.

Trimmer JS (1991) Immunological identification and characterization of a delayed rectifier $\mathrm{K}^{+}$channel polypeptide in rat brain. Proc Natl Acad Sci USA 88:10764-10768. 